\title{
IN VITRO ECTOMYCORRHIZA FORMATION BY MONOKARYOTIC AND DIKARYOTIC ISOLATES OF Pisolithus microcarpus IN Eucalyptus grandis ${ }^{1}$
}

\author{
Maurício Dutra Costa ${ }^{2}$, André Narvaes da Rocha Campos ${ }^{3}$, Matheus Loureiro Santos² e Arnaldo \\ Chaer Borges $^{2}$
}

\begin{abstract}
The formation of ectomycorrhizas by monokaryotic and dikaryotic isolates of Pisolithus microcarpus (Cooke \& Massee) G. Cunn. in Eucalyptus grandis W. Hill ex Maid. was studied by in vitro synthesis in Petri dishes. The formation of ectomycorrhizas was observed for all strains tested. Ectomycorrhizas formed by the monokaryotic strains presented a sheath of hyphae around the roots and a Hartig net limited to the epidermis layer, typical of the angiosperm ectomycorrhizas. Colonization rates, a measure of the number of ectomycorrhizas in relation to the total number of lateral root tips, varied from 23 to $62 \%$. Some monokaryotic strains stimulated the formation of lateral roots, promoting increases of up to $109 \%$ above the control. The presence of some of the isolates in the in vitro synthesis medium stimulated the production of thicker lateral root tips. The dimensions of the lateral roots tips and ectomycorrhizas varied from one isolate to the next, indicating a variation in their capacity to provoke morphological changes in the host plant roots. The dikaryotic strain M5M11 presented higher values for lateral root yield, number of ectomycorrhizas, and colonization percentage than the corresponding monokaryotic strains, M5 and M11. This indicated the possibility of selecting compatible performing monokaryotic isolates for the yield of superior dikaryotic strains. The set of monokaryotic strains tested varied greatly in their ability to colonize E. grandis roots and cause secondary metabolism-related morphological changes in roots, providing a wealth of model systems for the study of genetic, physiological, and morphogenetic processes involved in Pisolithus-Eucalyptus ectomycorrhiza formation.
\end{abstract}

Keywords:Ectomycorrhizal morphology., Mantle and Hartig net

\section{FORMAÇÃO DE ECTOMICORRIZAS IN VITRO POR ISOLADOS MONOCARIÓTICOS E DICARIÓTICOS DE Pisolithus microcarpus EM Eucalyptus grandis}

\begin{abstract}
RESUMO - A formação de ectomicorrizas por isolados monocarióticos e dicarióticos de Pisolithus microcarpus (Cooke \& Massee) G. Cunn. em Eucalyptus grandis W. Hill ex Maid. foi estudada usando-se o método de síntese in vitro em placas de Petri. A formação de ectomicorrizas foi observada para todas as linhagens testadas. Ectomicorrizas formadas pelas linhagens monocarióticas apresentaram manto de hifas circundando a raiz e rede de Hartig limitada à camada da epiderme, típica de ectomicorrizas de angiospermas. As percentagens de colonização, correspondendo ao número de ectomicorrizas em relação ao total de raízes laterais curtas, variaram de 23 a 62\%. Algumas linhagens monocarióticas estimularam a formação de raízes laterais curtas, promovendo aumentos médios de 109\% em comparação com o controle. A presença de alguns dos isolados no meio de síntese in vitro estimulou a produção de raízes laterais de maior diâmetro. As dimensões das raízes laterais e das ectomicorrizas variaram com o isolado inoculado, indicando variações dentro da população testada na capacidade de provocar mudanças morfológicas nas raízes da planta hospedeira. O dicário M5M11 apresentou maiores valores para produção de raízes laterais, número de ectomicorrizas e percentagem de
\end{abstract}

\footnotetext{
${ }^{1}$ Recebido em 24.05.2008 e aceito para publicação em 02.03.2010.

${ }^{2}$ Universidade Federal de Viçosa, UFV, Brasil. E-mail: <mdcosta@ufv.br>, <chaer@ufv.br>, <matheus.diagonal@gmail.com>.

${ }^{3}$ Instituto Federal de Educação Ciência e Tecnologia Sudeste de Minas Gerais, IFET-RP, Brasil. E-mail: <rochacampos@yahoo.com.br> .
} 
colonização em comparação com os isolados monocarióticos correspondentes, M5 e M11, indicando a possibilidade de se selecionar isolados compatíveis eficientes para a produção de dicários superiores. O conjunto de isolados monocarióticos testado variou quanto à capacidade de colonização das raízes de E. grandis e de causar mudanças morfológicas nas raízes relacionadas ao metabolismo secundário, constituindo- sistema-modelo para o estudo da genética, da fisiologia e dos processos morfogenéticos envolvidos na formação de ectomicorriza entre Pisolithus e Eucalyptus.

Palavras-chave: Morfologia de ectomicorrizas, Manto e Rede de Hartig.

\section{INTRODUCTION}

The ectomycorrhizal association of Pisolithus spp. with angiosperms and gymnosperms is widespread in the World (Marx et al., 1982). In Brazil, the importance of Pisolithus is derived from its association with Eucalyptus L'Hér., an exotic genus widely cultivated for timber, charcoal, and cellulose pulp for the paper industry. The benefits of ectomycorrhizas to the host plant include improved plant growth (BARROS et al., 1978; BURGESS et al., 1994; SILVA et al., 2007), increased phosphorus (P) uptake (BURGESS et al., 1993; TRAJANO et al., 2001; SILVA et al., 2007), higher tolerance to temperature stress (MARX and BRYAN, 1971) and soilborne pathogens (MARX, 1972; CHAKRAVARTY and UNESTAM, 1987), among other effects. For a long time, this has raised the interest of researchers in the functioning of the symbiosis aiming at an efficient and sustainable management of ectomycorrhizas in the field and forest nurseries.

In nature, Eucalyptus plants are found to be associated with only dikaryotic strains of Pisolithus. Monokaryotic strains, originated from the germination of basidiospores, soon mate with another sexually compatible monokaryotic strain, giving rise to a dikaryotic mycelium (KOPE and FORTIN, 1990; KOPE, 1992; CARVALHO et al., 1997). Reports of ectomycorrhizal formation by monokaryotic strains of a few basidiomycete ectomycorrhizal fungi have been found only for temperate gymnosperms species in in vitro synthesis (KROPP et al., 1987; GAY et al., 1994; KROPP, 1997).

Monokaryotic strains constitute a much simpler system for the understanding of the genetic control of mycorrhizal traits and other ecological and physiological aspects of the symbiosis. For example, monokaryotic strains have proven useful for the determination of a linkage map for Laccaria laccata (Scop.) Cooke, the number of linkage groups, and the genome size based on the cosegregation of RAPD markers (DOUDRICK et al., 1995). Monokaryons may yet be used to solve many problems of mycorrhizal research with strategies involving mutagenesis, protoplast fusion, and transformation (COSTA et al., 2002).

The inoculation of Pinus strobus L. with Laccaria bicolor (Maire) P. D. Orton has shown that monokaryons of this fungus display a wide range of root colonization capacities, varying from a complete inability to establish the association to highly infectious isolates (KROPP, 1997). In this study the inheritance of the ability for ectomycorrhizal colonization has shown that this trait is polygenically controlled. Also, for Pisolithus tinctorius (Pers.) Coker \& Couch, variations in the ability of dikaryotic strains originated from controlled crossings between monokaryons to form ectomycorrhizas with Pinus elliotti Eng. var. elliotti has shown that mycorrhizal formation is under polygenic control and that selected strains, obtained from specific crosses, could be used with selected host plants to improve ectomycorrhizal formation in a combined fungal and tree breeding program (ROSADO et al., 1994).

Certain morphological events that take place in the roots during the establishment of the symbiosis seem to be related to a few products of fungal secondary metabolism such as auxins and hypaphorine (GOGALA, 1991; GAY et al., 1994; BÉGUIRISTAIN and LAPEYRIE, 1997). In a study with auxin overproducer mutants of Hebeloma cylindrosporum Romagnesi, IAAoverproducing monokaryons showed higher mycorrhizal activity than the non-overproducers, indicating that, although the mycorrhizal activity in monokaryons is under polygenic control, high IAA production gives advantages in mycorrhizal formation (GAY et al., 1994). According to Wong and Fortin (1990), fungal phytohormones may enhance rhizogenic activity in the host plant providing an increased quantity of available colonization sites and consequently facilitating the establishment of the ectomycorrhizal symbiosis. Conversely, hypaphorine, a major indole compound accumulated in $P$. tinctorius mats in pure culture, causes a strong reduction of root hair elongation in Eucalyptus, 
suggesting that fungal molecules such as hypaphorine itself, could prevent root hair development in lateral roots as they emerge from colonized roots (BÉGUIRISTAIN and LAPEYRIE, 1997; DITENGOU et al., 2000; REBOUTIER et al., 2002).

Interactions between monokaryotic strains of $P$. microcarpus and Eucalyptus are still poorly explored, though knowledge of several physiological, genetic, and ecological aspects of the symbiosis has greatly advanced (CAIRNEY and CHAMBERS, 1997; COSTA et al., 2002; SILVA et al., 2007). Thus, the objective of this work was to verify whether monokaryotic strains of $P$. microcarpus, originated from the germination of basidiospores, were fully capable of forming ectomycorrhizas with E. grandis in vitro in Petri dishes, and to check whether such strains could cause the same morphological changes related to fungal secondary metabolism products in the roots of the host plant compared to other dikaryotic isolates included in this study.

\section{MATERIALAND METHODS}

\subsection{Monokaryotic and dikaryotic strains}

The monokaryotic strains 35, 75, 94, 95, 99, 109, 147,248 were obtained from the germination of spores collected from a $P$. microcarpus basidiocarp (voucher specimen VIC 26495), according to the method described by Carvalho et al. (1997), with some slight modifications. Briefly, approximately $0.05 \mathrm{~g}$ of spores was homogeneously spread onto $25 \mathrm{~mL}$ malt agar (20 g L${ }^{1}$ malt extract; pH 5.5, adjusted with $1.0 \mathrm{~mol} \mathrm{~L}^{-1} \mathrm{HCl}$ ). The Petri dishes were incubated for seven days at 25 ${ }^{\circ} \mathrm{C}$ and observed daily for the removal of contaminating colonies or disposal, if extensively contaminated. Cultures free of contamination were used to cut off $0.5 \times 0.5$ $\mathrm{cm}$ agar blocks containing spores. These blocks were then suspended in sterilized $0.5 \%$ Tween 80 to obtain a final spore concentration of $5 \times 10^{6} \mathrm{~mL}^{-1}$. One hundred microliters of the spore suspension thus obtained (500,000 spores) were spread onto an MNM medium (MARX, 1969) containing $2 \mathrm{~g} \mathrm{~L}^{-1}$ activated charcoal. Two disinfected seeds of Eucalyptus citriodora Hook were placed on the medium with the spores and incubated at $25^{\circ} \mathrm{C}$ for 3 days in the dark. Seed disinfection was done by treating seeds with $70 \%$ ethanol for one min, $20 \% \mathrm{H}_{2} \mathrm{O}_{2}$ for six min, followed by five rinses with sterilized distilled water. After germination, a single seedling was left per plate. The Petri dishes were then transferred to a growth chamber and incubated at $25{ }^{\circ} \mathrm{C}$ with $12 \mathrm{~h}$ of light $\left(100 \mu \mathrm{mol} \mathrm{m} \mathrm{m}^{-2} \mathrm{~s}^{-1}\right)$. From the $20^{\text {th }}$ day, newly formed colonies were transferred to fresh MNM, incubated for another 20 days at $25{ }^{\circ} \mathrm{C}$ and examined for the presence of clamp connections. Colonies without clamp connections were considered to be monokaryotic.

The monokaryotic strains, M5 and M11, isolated from a basidiocarp collected under a Eucalyptus sp. forest, and the corresponding reconstituted dikaryotic strain M5M11 were obtained from the ectomycorrhizal culture collection of Universidade Federal de Lavras, Lavras, Minas Gerais, Brazil. The dikaryotic strain Pt 90A, isolated from Eucalyptus sp., was obtained from the ectomycorrhizal culture collection of the Microbiology Department at Universidade Federal de Viçosa, Viçosa, Minas Gerais, Brazil.

\subsection{In vitro synthesis of ectomycorrhizas}

In vitro synthesis of ectomycorrhizas followed a protocol described by Burgess et al. (1996) with modifications. The experiment was conducted in $90 \times 20$ $\mathrm{mm}$ Petri dishes containing $20 \mathrm{~mL}$ of a nutrient medium with the following composition: $3 \mathrm{mmol} \mathrm{L}^{-1} \mathrm{~N} ; 0.7 \mathrm{mmol} \mathrm{L}^{-1}$ Ca; 0.6 mmol L-1 Cl; $0.5 \mathrm{mmol} \mathrm{L}^{-1} \mathrm{Mg}$; $0.5 \mathrm{mmol} \mathrm{L}^{-1} \mathrm{~S}$; 0.046 mmol L-1 K; $0.04 \mathrm{mmol} \mathrm{L}^{-1} \mathrm{P} ; 0.02 \mathrm{mmol} \mathrm{L}^{-1} \mathrm{Fe}$, $0.01 \mathrm{mmol} \mathrm{L}^{-1} \mathrm{~B} ; 2.28 \mu \mathrm{mol} \mathrm{L}-1 \mathrm{Mn} ; 0.2 \mu \mathrm{mol} \mathrm{L}-1 \mathrm{Zn}$; $0.005 \mu \mathrm{mol} \mathrm{L}{ }^{-1} \mathrm{Co} ; 0.03 \mu \mathrm{mol} \mathrm{L}-1$ Mo; $0.03 \mu \mathrm{mol} \mathrm{L}^{-1} \mathrm{Na}$; $100 \mu \mathrm{gL}^{-1}$ thiamine; $0.2 \mathrm{~g} \mathrm{~L}^{-1}$ glucose; $0.8 \%$ agar; and pH 5.8, adjusted with $1.0 \mathrm{~mol} \mathrm{~L}^{-1} \mathrm{HCl}$. The following salts were used to prepare the synthesis medium: $\mathrm{NH}_{4} \mathrm{NO}_{3}$, $\mathrm{KH}_{2} \mathrm{PO}_{4}, \mathrm{MgSO}_{4}, \mathrm{CaCl}_{2}, \mathrm{Ca}\left(\mathrm{NO}_{3}\right)_{2}, \mathrm{FeCl}_{3} \mathrm{H}_{3} \mathrm{BO}_{3}, \mathrm{MnSO}_{4}$, $\mathrm{ZnSO}_{4},\left(\mathrm{NH}_{4}\right)_{6} \mathrm{Mo}_{7} \mathrm{O}_{24}, \mathrm{NaCl}, \mathrm{CoCl}_{2}$. The surface of the medium was overlaid with a disc of autoclaved cellophane paper. Three agar discs cut off from the edge of actively growing twenty-day-old colonies of the ectomycorrhizal strains described above were placed along a line drawn on the bottom of the Petri dish, approximately, $3.0 \mathrm{~cm}$ away from the center of the plate (line A). The Petri dishes were incubated at $25^{\circ} \mathrm{C}$ for five days. To provide a support for the host plant seeds and prevent them from dropping off the correct position in the Petri dish, two hundred microliters of water-agar were spread along a line drawn $2.0 \mathrm{~cm}$ away from line A. Ten E. grandis seeds, previously disinfected as described above, were then placed along the water-agar layer, $2.0 \mathrm{~cm}$ away from the fungal colonies.

Revista Árvore, Viçosa-MG, v.34, n.3, p.377-387, 2010 
The experiment contained ten replicates of each treatment, corresponding to each monokaryotic and dikaryotic strain. A control treatment without fungal inoculation was also included. The plates were incubated at an angle of $70^{\circ}$ in a growth chamber under the same conditions as those described for spore germination. The formation of lateral roots and mycorrhizae were followed for 66 days. Ectomycorrhizal colonization was recorded only at the end of the experiment.

\subsection{Mantle and Hartig net formation}

To verify the formation of the mantle and Hartig net by the monokaryotic and dikaryotic strains, samples of ectomycorrhizas and of uninoculated lateral root tips from all treatments, stored in formaldehyde: ethanol 70\% ethanol: acetic acid (FEA, 5:90:5), were taken for morphological studies. Ectomycorrhizal and uninoculated lateral root tips were mounted in Jung Tissue Freezing Medium $^{\mathrm{TM}}$ and sectioned in a Leica CM 1850 cryomicrotome at $-28^{\circ} \mathrm{C}$. Unstained $35 \mu \mathrm{m}$-thick sections were observed by bright field microscopy with an Olympus BX 50 microscope and photographed with a PM-C35DX Olympus camera.

\subsection{Measurements of lateral root tips and ectomycorrhizas}

Samples of ten lateral roots and ten ectomycorrhizas were randomly taken for each strain and measured with an OSM 203749 Olympus micrometer mounted on a Carl Zeiss microscope. The measurements corresponded to root and ectomycorrhiza length and diameter of the basal, middle, and apical thirds of lateral root tips and ectomycorrhizas. Mantle thickness was measured indirectly in the photographs of the sections of the ectomycorrhizas.

\subsection{Statistical analysis}

The experiment was installed in a completely randomized design with ten replicates. Data were submitted to variance analysis and media were grouped by the Scott-Knott test at 5\% probability whenever pertinent. Pearson's simple correlation was also determined for the number of lateral root tips and ectomycorrhizal colonization.

\section{RESULTS}

\subsection{Formation and morphological characterization of ectomycorrhizas}

All monokaryotic and dikaryotic isolates were capable of forming ectomycorrhizas with E. grandis under the conditions used in the experiment (Table 1). Ectomycorrhizas could be clearly observed from the $8^{\text {th }}$ to the $12^{\text {th }}$ day after seed germination and were exclusively formed with the newly emerged lateral root tips. Despite the long incubation in vitro (66 days), ectomycorrhizas could be observed throughout the experiment, being either newly formed young ones or older, senesced mycorrhizas. No data were recorded relative to age of ectomycorrhizal and lateral root tips.

Ectomycorrhizal formation started by contact between the hyphae growing on the support medium and the lateral root tips. The contact phase occurred two to three days after seed germination and depended greatly on the length of the main root axis, root extension, and lateral root tip emergence. Hyphae were first loosely attached to the lateral root tips and progressed to form dense layers of mycelium over the entire seedling root so that, most of the time, the visualization of ectomycorrhizas was only possible by removing excess mycelium from the roots, followed by observation under a stereomicroscope. In the intermediary phases of colonization, patches of vigorous mycelial growth were observed adjacent to or over discrete regions of the seedling roots, indicating improved fungal growth on exudates and sloughed-off tissue produced by the plants. As contact of the fungus with young lateral root tips and lateral root primordia occurred, a strong inhibition of root hair development was observed.

The synthesized ectomycorrhizas were monopodial, unbranched and mostly isolated, but sometimes present in clusters of three to five ectomycorrhizas (Figure 1). Despite the variation observed for mycelial color of the monokaryotic and dikaryotic strains, variation in ectomycorrhizal color was narrower and corresponded mostly to beige, light yellow, or light orange, being similar to mycelial color in pure culture.

Anatomical sectioning showed the presence of a hyphal sheath or mantle around the lateral root tips and a Hartig net limited to the epidermal intercellular spaces (Figure 1). Mantle thickness varied from one isolate to the next (10 to $36 \mu \mathrm{m}$ ), but no correlation 
Table 1 - Number of lateral root tips, ectomycorrhizas, and root tip colonization percentage of Eucalyptus grandis seedlings inoculated with monokaryotic (35, 75, 94, 95, 99, 109, 147, 248, M5, M11) and dikaryotic (M5M11, Pt 90A) isolates of Pisolithus microcarpus, after 31 and 66 days of plant growth in vitro.

Tabela 1 - Número de raízes laterais curtas, ectomicorrizas e percentagem de colonização de plântulas de Eucalyptus grandis inoculadas com isolados monocarióticos (35, 75, 94, 95, 99, 109, 147, 248, M5, M11) e dicarióticos (M5M11, Pt 90A) de Pisolithus microcarpus, após 31 e 66 dias de crescimento in vitro.

\begin{tabular}{|c|c|c|c|c|c|c|}
\hline $\begin{array}{l}\text { Isolate } \\
\text { number }\end{array}$ & $\begin{array}{c}\text { Lateral } \\
\text { roots/plan }\end{array}$ & Increase $^{a}(\%)$ & $\begin{array}{c}\text { Lateral } \\
\text { roots/plant }\end{array}$ & Increase $^{a}(\%)$ & $\begin{array}{c}\text { Ectomycorrhizas/ } \\
\text { plant }\end{array}$ & $\begin{array}{c}\text { Colonization } \\
(\%)\end{array}$ \\
\hline \multicolumn{3}{|c|}{31 days } & \multicolumn{4}{|c|}{66 days } \\
\hline 35 & $6.2 \mathrm{a}$ & 130 & $8.2 \mathrm{a}$ & 86 & $2.2 \mathrm{~b}$ & $27 \mathrm{c}$ \\
\hline 75 & $4.3 \mathrm{~b}$ & 59 & $5.3 \mathrm{c}$ & 20 & $3.1 \mathrm{~b}$ & 59 a \\
\hline 94 & $7.3 \mathrm{a}$ & 170 & $9.2 \mathrm{a}$ & 109 & 3.9 a & $42 \mathrm{~b}$ \\
\hline 95 & $3.1 \mathrm{c}$ & 15 & $7.3 \mathrm{~b}$ & 66 & $3.5 \mathrm{a}$ & $48 \mathrm{~b}$ \\
\hline 99 & $4.6 \mathrm{~b}$ & 70 & $6.1 \mathrm{c}$ & 39 & $3.1 \mathrm{~b}$ & $51 \mathrm{~b}$ \\
\hline 109 & $6.6 \mathrm{a}$ & 144 & $7.3 \mathrm{~b}$ & 66 & $4.0 \mathrm{a}$ & 55 a \\
\hline 147 & $4.8 \mathrm{~b}$ & 78 & $7.5 \mathrm{~b}$ & 70 & $3.6 \mathrm{a}$ & $48 \mathrm{~b}$ \\
\hline 248 & $3.1 \mathrm{c}$ & 15 & $4.2 \mathrm{c}$ & -5 & $2.6 \mathrm{~b}$ & 62 a \\
\hline M5 & $3.5 \mathrm{c}$ & 30 & $6.1 \mathrm{c}$ & 39 & $2.1 \mathrm{~b}$ & $35 \mathrm{~b}$ \\
\hline M11 & $2.5 \mathrm{c}$ & -7 & $5.7 \mathrm{c}$ & 30 & $1.3 \mathrm{c}$ & $23 \mathrm{c}$ \\
\hline M5M11 & $4.9 \mathrm{~b}$ & 81 & $6.8 \mathrm{~b}$ & 55 & $2.9 \mathrm{~b}$ & $43 \mathrm{~b}$ \\
\hline Pt $90 \mathrm{~A}$ & $4.0 \mathrm{~b}$ & 48 & $6.7 \mathrm{~b}$ & 52 & $2.7 \mathrm{~b}$ & $40 \mathrm{~b}$ \\
\hline Control & $2.7 \mathrm{c}$ & 0 & $4.4 \mathrm{c}$ & 0 & $0.0 \mathrm{~d}$ & $0 \mathrm{~d}$ \\
\hline Mean $^{\mathrm{b}}$ & 4.6 & 70 & 6.7 & 52 & 2.9 & 44 \\
\hline
\end{tabular}

For each column, values followed by the same letter are not statistically different by the Scott-Knot test at $5 \%$ probability. a/ Increase in lateral tip emergence in relation to the control mean [(treatment mean - control mean)/control mean x 100]. b/ The mean does not include the control treatment.
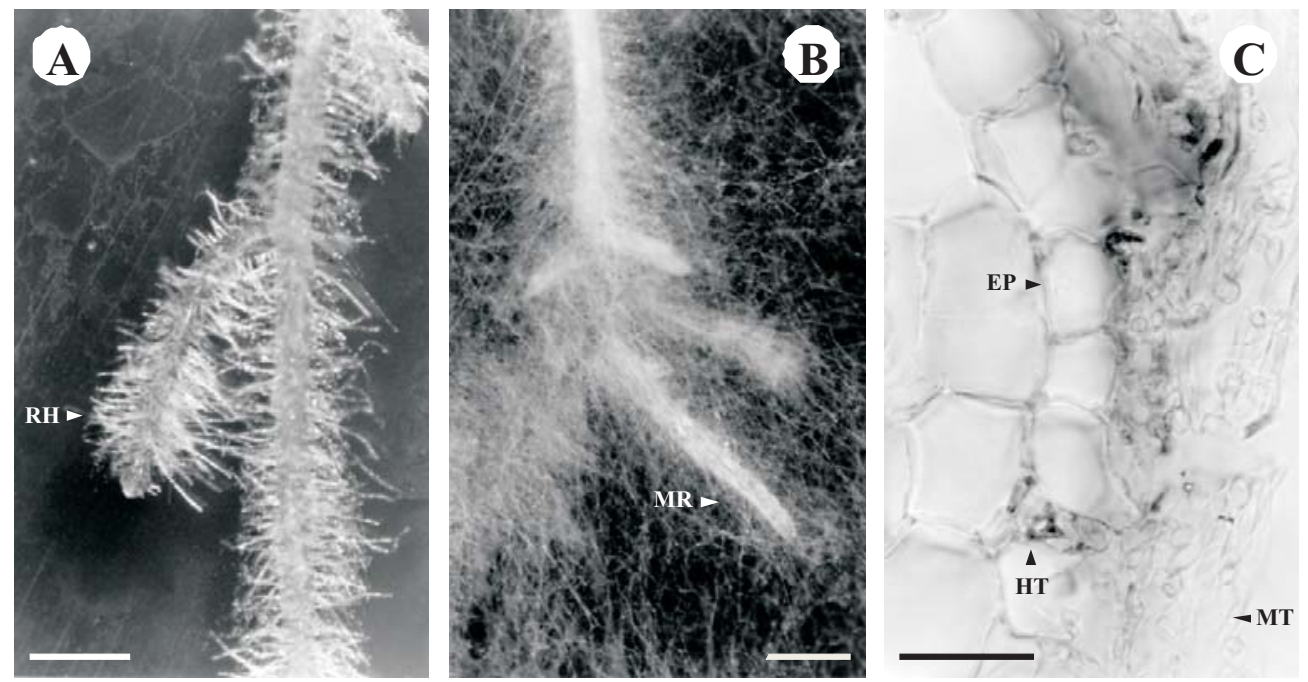

Figure 1 - Roots and ectomycorrhizas of Eucalyptus grandis grown in vitro. (A) Uninoculated control roots showing abundant root hairs (RH). (B) Mycorrhized root (MR) showing emanating hyphae of the monokaryotic isolate 94. (C) Transversal section of an ectomycorrhiza of the monokaryotic isolate 75 at the beginning of Hartig net (HT) formation. Notice the thickness of the mantle and the presence of non-elongated epidermal cells (EP) of the pre-Hartig net zone. Bars: $\mathrm{A}=300 \mu \mathrm{m}, \mathrm{B}=500 \mu \mathrm{m}$, and $\mathrm{C}=20 \mu \mathrm{m}$.

Figura 1 - Raízes e ectomicorrizas de Eucalyptus grandis- cultivadas in vitro. (A) Raiz não-inoculada do tratamento--controle mostrando abundante produção de pelos radiculares $(R H)$. Raíz micorrizada (MR) mostrando hifas emanadas do isolado monocariótico 94. (C) Seção transversal de uma ectomicorriza do isolado monocariótico 75 no início da formação da rede de Hartig (HT). Notam-se a espessura do manto e a presença de células epidérmicas nãoelongadas típicas da região pré-rede de Hartig. Barras: $A=300 \mu \mathrm{m}, B=500 \mu \mathrm{m}$ e $C=20 \mu \mathrm{m}$. 
was established between this trait and isolate aggressiveness due to the limited number of sections observed and photographed. Mantle development allowed the distinction of layers of outer prosenchyma (mantle with air spaces) and inner synenchyma (mantle with no air spaces) closely attached to roots.

In the mantle layer formed by isolates Pt 90A, M5M11, and 95, orange to brown, spherical to oval, sometimes irregularly shaped incrustations were also observed. The spherical incrustations were 4.0 to $7.0 \mu \mathrm{m}$ in diameter and their chemical composition was not determined.

The diameter of the apical, middle, and basal thirds of the ectomycorrhizas as well as the length of the ectomycorrhizal root tips were measured to characterize the morphological changes brought about by the colonization of the root system by the monokaryotic and dikaryotic isolates. Except for root tip length, root colonization by some of the isolates caused increases in the apical, middle, and basal diameters when compared to the lateral root tips produced by uninoculated seedlings (Table 2). Ectomycorrhizal root tips showed a slight tendency to taper from the base to the apex and were thicker than unmycorrhized tips (Table 2). The monokaryotic isolates M5 and Mid not cause changes in ectomycorrhizal lateral root tip morphology (Table 2). However, the corresponding dikaryotic strain M5M11 was capable of stimulating increases in root tip dimensions to values above those of the control treatment. In general, the isolates that caused the less marked morphological changes in mycorrhized lateral root tips were the monokaryons M5, M11, and the dikaryon M5M11 (Table 2).

The presence of unassociated mycelium in the vicinity of host roots was capable of causing changes in lateral root tip morphology (Table 2). Similarly to mycorrhizal root tips, some isolates were capable of inducing increases in apical, middle, and basal diameters of the nonmycorrhizal lateral root tips, showing that morphological changes may occur even without a direct association of the fungus with the host plant roots. For mycorrhized, as well as nonmycorrhized lateral root tips (Tables 2), root tip length was always the same as that observed for the control, indicating that cell elongation along the lateral root tip axis was not stimulated to the same extent as root radius.

Table 2 - Apex, middle, and basal diameters and length of ectomycorrhizas (ECTO) and non-mycorrhizal lateral root tips (LATR) of Eucalyptus grandis seedlings inoculated with monokaryotic (35, 75, 94, 95, 99, 109, 147, 248, M5, M11) and dikaryotic (M5M11, Pt 90A) isolates of Pisolithus microcarpus, recorded after 66 days of plant growth in vitro

Tabela 2 - Diâmetros apical, basal e médio e comprimento das ectomicorrizas (ECTO) e de raízes laterais finas não- micorrizadas (LATR) de mudas de Eucalyptus grandis inoculadas com isolados monocarióticos (35, 75, 94, 95, 99, 109, 147, 248, M5, M11) e dicarióticos (M5M11, Pt 90A) de Pisolithus microcarpus, após 66 dias de crescimento da planta in vitro.

\begin{tabular}{|c|c|c|c|c|c|c|c|c|}
\hline \multirow{3}{*}{$\begin{array}{l}\text { Isolate } \\
\text { number }\end{array}$} & \multicolumn{6}{|c|}{ Diameter $\mu \mathrm{m}$} & \multicolumn{2}{|c|}{ Length mm } \\
\hline & \multicolumn{2}{|c|}{ Apex } & \multicolumn{2}{|c|}{ Middle } & \multicolumn{2}{|c|}{ Base } & & \\
\hline & ЕСТО & LATR & ЕСТО & LATR & ЕСТО & LATR & СTO & LATR \\
\hline 35 & $184 \mathrm{~b}$ & 119 c & 199 a & $146 \mathrm{~b}$ & 226 a & $166 \mathrm{~b}$ & $1.31 \mathrm{a}$ & $1.15 \mathrm{a}$ \\
\hline 75 & 191 a & $133 \mathrm{~b}$ & 223 a & $154 \mathrm{~b}$ & 239 a & $187 \mathrm{a}$ & $0.94 \mathrm{a}$ & $1.40 \mathrm{a}$ \\
\hline 94 & 192 а & $115 \mathrm{c}$ & 213 a & $143 \mathrm{~b}$ & $230 \mathrm{a}$ & $165 \mathrm{~b}$ & 0.88 a & $1.26 \mathrm{a}$ \\
\hline 95 & $180 \mathrm{~b}$ & $130 \mathrm{~b}$ & 202 a & $147 \mathrm{~b}$ & 214 a & $159 \mathrm{~b}$ & $0.76 \mathrm{a}$ & $1.14 \mathrm{a}$ \\
\hline 99 & 196 a & $140 \mathrm{~b}$ & 220 a & $161 \mathrm{a}$ & 237 a & 197 a & 0.89 a & $1.17 \mathrm{a}$ \\
\hline 109 & $185 \mathrm{~b}$ & $144 \mathrm{~b}$ & 218 a & 166 a & 233 a & 194 a & $1.03 \mathrm{a}$ & $1.29 \mathrm{a}$ \\
\hline 147 & 200 a & $127 \mathrm{~b}$ & 224 a & $154 \mathrm{~b}$ & 243 a & 183 a & $0.91 \mathrm{a}$ & $1.09 \mathrm{a}$ \\
\hline 248 & 196 a & $121 \mathrm{c}$ & 219 a & $152 \mathrm{~b}$ & $231 \mathrm{a}$ & $170 \mathrm{~b}$ & $1.10 \mathrm{a}$ & $1.17 \mathrm{a}$ \\
\hline M5 & $146 \mathrm{c}$ & $84 \mathrm{e}$ & $165 \mathrm{c}$ & $107 \mathrm{c}$ & $184 \mathrm{~b}$ & $139 \mathrm{~b}$ & $0.97 \mathrm{a}$ & $0.98 \mathrm{a}$ \\
\hline M11 & $135 \mathrm{c}$ & $115 \mathrm{c}$ & $161 \mathrm{c}$ & $131 \mathrm{c}$ & $178 \mathrm{~b}$ & $156 \mathrm{~b}$ & $0.77 \mathrm{a}$ & $1.37 \mathrm{a}$ \\
\hline M5M11 & $171 \mathrm{~b}$ & 118 c & $186 \mathrm{~b}$ & 139 b & 207 b & $169 \mathrm{~b}$ & $1.05 \mathrm{a}$ & $1.55 \mathrm{a}$ \\
\hline Pt $90 \mathrm{~A}$ & $194 \mathrm{a}$ & $164 \mathrm{a}$ & 229 a & 172 a & 262 a & 188 a & $1.25 \mathrm{a}$ & $1.30 \mathrm{a}$ \\
\hline Control & - & $102 \mathrm{~d}$ & - & $121 \mathrm{c}$ & - & $151 \mathrm{~b}$ & - & $1.01 \mathrm{a}$ \\
\hline Mean $^{\mathrm{a}}$ & 180 & 126 & 205 & 148 & 224 & 173 & 0.99 & 1,24 \\
\hline
\end{tabular}

For each column, values followed by the same letter are not statistically different by the Scott-Knott test at $5 \%$ probability. a/ The mean does not include the control treatment.

Revista Árvore, Viçosa-MG, v.34, n.3, p.377-387, 2010 


\subsection{Root tip emergence and ectomycorrhizal colonization}

The formation of root tips was followed along a 66-day period and statistical analysis was performed on days 31 and 66 of plant growth. After 31 days, the number of lateral root tips formed varied from one isolate to the next and corresponded to 2.5 to 7.3 lateral root tips/plant (Table 1). The mean number of root tips in the presence of all the monokaryotic and dikaryotic isolates studied (4.6 lateral root tips/plant) was 70\% higher than that for the control treatment, without fungal inoculation (2.7 lateral root tips/plant; Table 1). For individual isolates with lateral root tip emergence significantly higher than that of the control, the mean for lateral root tip emergence varied from 4.0 to 7.3 lateral root tips/plant, corresponding to increases of 48 to $170 \%$ over the control. At the end of 66 days, the stimulation of lateral root tip formation was the highest in the treatments with isolates 35 and 94, followed by those with isolates 95, 109, 147, M5M11, and Pt 90A (Table 1). The increases in root tip production varied from 20 to $109 \%$ with a mean increase of $52 \%$ in relation to the control treatment (Table 1). The number of ectomycorrhizas formed varied from 1.3 to 4.0 ectomycorrhizas/plant and colonization rates, representing the number of mycorrhizal root tips over the total number of root tips produced, varied from 23 to $62 \%$ (Table 1 ). A positive correlation was found between the production of lateral root tips and ectomycorrhizal colonization $(0.6398 ; \mathrm{p}<0.05)$

At the end of the experiment, the isolates were grouped into three classes according to the results obtained for lateral root tip yield: Class III group isolates with means not statistically different from that of the control treatment by the Scott-Knott test at 5\% probability (75, 99, 248, M5, M11); Class II group isolates for which means for lateral root tip yield are statistically higher than that of the control $(95,109,147$, M5M11, Pt 90A); and Class I includes the isolates with means higher than those for the isolates belonging to Class II and Class III $(35,94)$. The mean number of lateral root tips produced for each one of the three classes of isolates along the incubation time is shown in Figure 2. In general, lateral root tip formation reached a maximum around the $55^{\text {th }}$ day of plant growth. From this point on, the number of lateral root tips tended to stabilize.

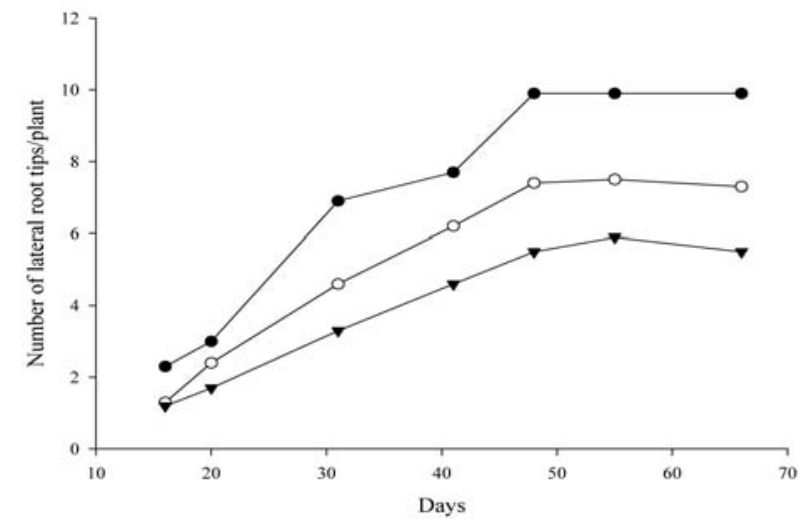

Figure 2 - Mean emergence of lateral root tips in Eucalyptus grandis seedlings inoculated with Pisolithus microcarpus isolates of classes I (O), II (O), and III $(\boldsymbol{\nabla})$, over a 66-day period. Isolates were grouped according to the results of the ScottKnott test at $5 \%$ probability. Class I group isolates $(35,94)$ with means for lateral root tip formation statistically higher than the means for isolates of Class II and Class III. Class II group isolates (95, 109, 147, M5M11, Pt 90A) with means for lateral root tip formation statistically higher than the means for isolates of Class III. Class III corresponds to the isolates $(75,99,248, \mathrm{M} 5$, M11) whose means are not statistically different from the control mean.

Figura 2 - Média do número de raízes laterais curtas em mudas de Eucalyptus grandis inoculadas com isolados de Pisolithus microcarpus das classes I ( ○), II ( ○ ), e III ( $\nabla$ ), após 66 dias de crescimento in vitro. Os isolados foram agrupados de acordo com os resultados do teste Scott-Knott a 5-\% de probabilidade. Os isolados da classe I $(35,94)$ apresentam médias de raízes laterais curtas estatisticamente superiores às das classes II e III. A classe II agrupou os isolados (95, 109, 147, M5M11, Pt 90A) com médias de raízes laterais curtas estatisticamente superiores à dos isolados da classe III. Classe III corresponde aos isolados (75, 99, 248, M5, M11) cujas médias não são estatisticamente diferentes da média do tratamento controle.

\section{DISCUSSION}

The technique employed in this experiment allowed the efficient synthesis of ectomycorrhizas for the monokaryotic as well as for the dikaryotic strains studied. Despite the use of smaller Petri dishes than those used by Burgess et al. (1996), ectomycorrhizal formation and lateral root tip emergence could be followed with ease. Plantlets appeared healthy and well nourished

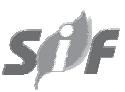

Revista Árvore, Viçosa-MG, v.34, n.3, p.377-387, 2010 
throughout the experiment. It was not our interest to synchronize ectomycorrhiza age and, therefore, ectomycorrhizal formation was evaluated only at the end of the experiment with maximum care to sample only fresh, morphologically intact, fully developed ectomycorrhizas for anatomical studies.

The main morphological features of the ectomycorrhizas formed by the monokaryotic strains indicated that these were typical of angiosperm ectomycorrhizas, containing a hyphal sheath or mantle around the roots and a Hartig net limited to the intercellular spaces of the root epidermis (BRUNDRETT et al., 1996; SILVA et al., 2007). Although no relationship could be established between mantle thickness and isolate aggressiveness (BURGESS et al., 1994), the presence of the mantle and the Hartig net indicated that all isolates tested were compatible with the host plant. Signs of isolate-host incompatibility such as the deposition of tannins in root tissue, lysis of hyphae and of epidermal and outer cortical cells of roots were not observed.

The presence of spherical incrustations in the mantle of ectomycorrhizas formed by isolates Pt 90A, M5M11, and 95 could be an indication of incompatibility reactions between the isolates and the host plant, but this could not be elucidated since the chemical composition of such structures was not determined. For in vitro synthesis experiments, high glucose concentrations lead to the accumulation of phenolics depositions in the plant cells and the formation of irregular mantles (DUDDRIDGE, 1986; GIBSON and DEACON, 1990). BURGESS et al. (1994) previously optimized the carbohydrate concentration in the synthesis medium used in our experiment and it seems unlikely that the observed structures may be sites of phenolics accumulation in the mantle due to excessive carbon. Alternatively, such incrustations may constitute sites of calcium oxalate deposition as already observed in the mantle of ectomycorrhizal roots of Pinus radiata D. Don and Eucalyptus marginata Donn. ex Sm. (MALAJCZUK and CROMACK, 1982).

Nonmycorrhizal lateral root tips produced in the presence of some of the monokaryons were thicker than those of uninoculated control seedlings, indicating that such isolates were capable of inducing morphological changes in the lateral root tips without an apparent colonization of the host root. Some other isolates were not able to cause changes in the diameter of mycorrhized as well as unmycorrhized lateral root tips. This could be related to an incapacity to synthesize plant hormones such as IAA. The application of IAA to non-inoculated eucalypt plantlets to simulate fungal secretion induced the formation of slow-growing, swollen, and highly branched roots, superficially similar to ectomycorrhizas (HORAN, 1991). However, IAA failed to generate characteristics typical of ectomycorrhizas such as elongated epidermal cells, among others traits. This information does not allow us to elucidate whether failure of some isolates to promote thicker lateral root tips is linked to a reduced synthesis of IAA, but suggests that such variations in monokaryons may be important to elucidate unknown functions required for ectomycorrhizal formation.

The formation of ectomycorrhizas resulted in the inhibition of root hairs in colonized tips and this is in agreement with a putative synthesis of hypaphorine (DITENGOU et al., 2000; REBOUTIER et al., 2002) by all isolates, indicating that some secondary metabolismdependent processes were fully functional in association with all the monokaryotic and dikaryotic strains.

The monokaryotic and the dikaryotic strains varied in their ability to stimulate lateral root tip emergence, ectomycorrhizal formation and, consequently, ectomycorrhizal colonization. Genetic work with some ectomycorrhizal fungi has already shown that ectomycorrhizal formation is under polygenic control (ROSADO et al., 1994; KROPP, 1997) and that both monokaryotic as well as dikaryotic strains possess different abilities to colonize plant roots. The dikaryotic strain M5M11, produced in a crossing between the monokaryotic strains M5 and M11, promoted higher colonization rates and numbers of lateral root tips and ectomycorrhizas than the corresponding monokaryons. This represented a gain over the parental monokaryons used to synthesize M5M11 and exemplifies how monokaryons can be used to produce strains with better ectomycorrhizal performance by means of selection and crossings (ROSADO et al. 1994). In fact, percentage ectomycorrhizal formation has been shown to involve a significant additive genetic component (ROSADO et al., 1994) and this may explain improvements in ectomycorrhizal colonization achieved with the dikaryotic strain M5M11.

The positive correlation found between the number of lateral root tips and the ectomycorrhizal colonization (0.6398; $\mathrm{p}<0.05)$ corroborates the hypothesis that an increased rhizogenic activity, resulting in increased 
number of infection sites, benefits the establishment of the ectomycorrhizal symbiosis (WONG and FORTIN, 1990). However, some monokaryons that formed ectomycorrhizas with E. grandis did not stimulate lateral root tip formation, indicating that, although rhizogenic activity stimulation increases ectomycorrhizal formation, it is not essential for the establishment of the symbiosis.

Lateral root tip formation was followed throughout a 66-day incubation period and showed two distinct phases of root tip production. The first phase corresponded to a period of linear increase of lateral root tip number and a second one when lateral root tip emergence stabilized. The Linear increase was observed up to approximately the $48^{\text {th }}$ day of plant growth. Class I and Class II isolates substantially improved the mean yield of lateral roots. Burgess et al. (1996) also observed the same kind of stimulus of lateral tip formation. In their work, lateral root tip emergence was also shown to be stimulated in the presence of exudates from Pisolithus sp. and the alterations in root tip emergence patterns of inoculated seedlings were supposedly attributed to exogenous auxins from the fungus overriding the normal internal controls of the root. Similar effects have been observed previously and attributed to ectomycorrhizal fungi altering the normal host hormone balance either by supplying hormones (GAY and DEBAUD, 1987; GOGALA, 1991; GAY et al., 1994; GEA et al., 1994) or by eliciting an alteration in endogenous hormone level (GOGALA, 1991). Also, the ability of $H$. cylindrosporum to form ectomycorrhizas with $P$. pinaster is improved in monokaryotic and dikaryotic auxin overproducer strains, indicating a role for IAA in the formation of ectomycorrhizas (GAY et al., 1994).

In conclusion, the monokaryotic strains studied in this work were capable of forming ectomycorrhizas with E. grandis and present a wide variation in the morphogenetic changes that take place in the root system during the contact and establishment of the symbiosis. Such variation, so far observed for a small population of monokaryotic individuals, can be used to elucidate how quantitative and qualitative aspects of the plant-fungus symbiosis interact to result in the highly complex and intricate structure of an ectomycorrhiza. Reports on the interaction of Eucalyptus spp. with monokaryotic strains of Pisolithus are rare (SILVA et al., 2007). Success in the isolation of monokaryotic strains of Eucalyptus-specific Pisolithus species, which have already been achieved (CARVALHO et al., 1997), may eventually allow the development of both classical and molecular biology studies on the genetics of Pisolithus taking advantage of the far simpler genetic system represented by monokaryons.

\section{REFERENCES}

BARROS, N.F.; BRANDI, R.M.; REIS, M.S. Micorriza em eucalipto. Uma revisão sobre a morfologia, a fisiologia e os efeitos mútuos da associação fungo-planta. Rev. Árvore, v.2, p.130-140, 1978.

BÉGUIRISTAIN T.; LAPEYRIE, F. Host plant stimulates hypaphorine accumulation in Pisolithus tinctorius hyphae during ectomycorrhizal infection while excreted fungal hipaphorine controls root hair development. New Phytol., v.136, p.525-532, 1997.

BURGESS, T.; DELL, B.; MALAJCZUK, N. Variation in mycorrhizal development and growth stimulation by 20 Pisolithus isolates inoculated onto Eucalyptus grandis W. Hill ex Maiden. New Phytol., v.127, p.731-739, 1994.

BURGESS, T.; DELL, B.; MALACJZUK, N. In vitro synthesis of Pisolithus-Eucalyptus ectomycorrhizas: synchronization of lateral tip emergence and ectomycorrhizal development. Mycorrhiza, v.6, p.189-196, 1996.

BURGESS, T.; MALAJCZUK, N.; GROVE, T.S. The ability of 16 ectomycorrhizal fungi to increase growth and phosphorus uptake by Eucalyptus globulus Labill and E. diversicolor F. Muell. Plant Soil, v.153, p.155-164, 1993.

BRUNDRETT, M.; BOUGHER, N.; DELL, B.; GROVE, T.; MALAJCZUK, N. Working with Mycorrhizas in Forestry and Agriculture. ACIAR Monograph 32. Canberra: Pirie Printers, 1996. 374p

CAIRNEY, J.W.G.; CHAMBERS S.M. Interactions between Pisolithus tinctorius and its host: a review of current knowledge. Mycorrhiza, v.7, p.117-131, 1997.

CARVALHO, D.; ROSADO, S.C.S.; SOUZA, A.M.; OLIVEIRA, A.F. Produção de culturas monocarióticas e compatibilidade sexual intra- e interpopulacional para o fungo ectomicorrízico Pisolithus tinctorius. Cerne, v.3, p.143-160, 1997. 
CHAKRAVARTY, P.; UNESTAM, T. Mycorrhizal fungi prevent diseases in stressed pine seedlings. J. Phytopathol., v.118, p.335-340, 1987.

COSTA, M.D.; BORGES, A.C.; KASUYA, M.C.M.; QUEIROZ, M.V. Physiology and genetics of ectomycorrhiza formation in the PisolithusEucalyptus symbiosis. Tópicos Ci. Solo, v.2, p.143-193, 2002.

DITENGOU, F.A.; BÉGUIRISTAIN, T.; LAPEYRIE, F. Root hair elongation is inhibited by hipaphorine, the indole alkaloid from the ectomycorrhizal fungus Pisolithus tinctorius, and restored by indole-3-acetic acid. Planta, v.211, p.722-728, 2000.

DOUDRICK, R.L.; RAFFLE, V.L.; NELSON, C.D.; FURNIER, G.R. Genetic analysis of homokarions from a basidiome of Laccaria bicolor using random amplified polymorphic DNA (RAPD). Mycol. Res., v.99, p.1362-1366, 1995.

DUDDRIDGE, J.A. The development and ultrastructure of ectomycorrhizas. IV. Compatible and incompatible interactions between Suillus grevillei (Klotzsch) Sing. and a number of ectomycorrhizal hosts in vitro in the presence of exogenous carbohydrate. New Phytol., v.103, p.465-471, 1986.

GAY, G.; DEBAUD, J.C. Genetic study on indole-3acetic acid production by ectomycorrhizal Hebeloma species: inter and intraspecific variability in homo- and dikaryotic mycelia. Appl. Microbial Biotech., v.26, p.141-146, 1987.

GAY, G.; NORMAND, L.; MARMEISSE, R.; SOTTA, B.; DEBAUD, J.C. Auxin overproducer mutants of Hebeloma cylindrosporum Romagnesi have increased mycorrhizal activity. New Phytol., v.128, p.645-657, 1994.

GEA, L.; NORMAND, L.; VIAN, B.; GAY, G. Structural aspects of ectomycorrhizae of Pinus pinaster (Ait.) Sol. formed by an IAAoverproducer mutant of Hebeloma cylindrosporum Romagnesi. New Phytol., v.128, p.659-670, 1994.

GIBSON, F.; DEACON, J.W. Establishment of ectomycorrhizas in aseptic culture: effects of glucose, nitrogen and phosphorus in relation to successions. Mycol. Res., v.94, p.166-172, 1990.
GOGALA, N. Regulation of mycorrhizal infection by hormonal factors produced by hosts and fungi. Experientia, v.47, p.331-340, 1991.

HORAN, D. Infection process in eucalypt mycorrhizas. Canberra: Australian National University, 1991. 151p.: il. (tese de Doutorado)

KOPE, H.H. Interactions oh heterokaryotic and homokaryotic mycelium of sibling isolates of ectomycorrhizal fungus Pisolithus arhizus. Mycologia, v.84, p.659-667, 1992.

KOPE, H.H.; FORTIN, J.A. Germination and comparative morphology of basidiospores of Pisolithus arhizus. Mycologia, v.82, p.350-357, 1990.

KROPP, B. Inheritance of the ability for the ectomycorrhizal colonization of Pinus strobus by Laccaria bicolor. Mycologia, v.89, p.578-585, 1997.

KROPP, B.R., MCAFEE, B.J.; FORTIN, J.A. Variable loss of ectomycorrhizal ability in monokaryotic and dikaryotic cultures of Laccaria bicolor. Can. J. For. Res., v.65, p.500-504, 1987.

MALAJCZUK, N.; CROMACK, K. Accumulation of calcium oxalate in the mantle of ectomycorrhizal roots of Pinus radiata and Eucalyptus marginata. New Phytol., v.92, p.527-531, 1982.

MARX, D.H. The influence of ectotrophic mycorrhizal fungi on the resistance of pine roots to pathogenic infections. I. Antagonism of mycorrhizal fungi to root pathogenic fungi and soil bacteria. Phytopathol., v.59, p.153-163, 1969.

MARX, D.H. Ectomycorrhizae as biological deterrents to pathogenic root infections. Ann. Rev. Phytopathol., v.10, p.429-454, 1972.

MARX, D.H.; BRYAN, W.C. Influence of ectomycorrhizae on survival and growth of aseptic seedlings of loblolly pine at high temperature. For. Sci., v.17, p.37-41, 1971.

MARX, D.H.; RUEHLE, J.L.; KENNEDY, D.S.; CORDELL, C.E.; RIFFLE, J.W.; MOLINA, R.J.; PAWUK, W.H.; NAVRATIL, S.; TINUS, R.W.; GOODWIN, O.C. Commercial vegetative inoculum of Pisolithus tinctorius and inoculation techniques for development of ectomycorrhizae on container-grown tree seedlings. For. Sci., v.28, p.373-400, 1982. 
REBOUTIER, D.; BIANCHI, M.; BRAULT, M.; ROUX, C.; DAUPHIN, A.; RONA, J.P.; LEGUE, V.; LAPEYRIE, F.; BOUTEAU, F. Indolic compound hypaphorine produced by ectomycorrhizal fungi interferes with auxin action and evokes early responses in nonhost Arabidopsis thaliana. Mol. Plant-Microbe Interact., v.15, p.932-938, 2002.

ROSADO, S.C.S.; KROPP, B.R.; PICHÉ, Y. Genetics of ectomycorrhizal symbiosis II. Fungal variability and heretability of ectomycorrhizal traits. New Phytol., v.126, p.111-117, 1994.
SILVA, M.A.; COSTA, M.D. ; ROCHA, R.B.; BORGES, A.C. Formação de ectomicorrizas por monocários e dicários de Pisolithus sp. e interações nutricionais em Eucalyptus grandis. R. bras Ci. Solo, v.31, p.917-929, 2007.

TRAJANO, M.A.T.; KASUYA, M.C.M.; TÓTOLA, M.R.; BORGES, A.C.; NOVAIS, R.F. Suprimento de fósforo e formação de micorrizas em mudas de eucalipto em sistema de raízes divididas. Rev. Árvore, v. 25, p.193-201, 2001.

WONG, K.K.Y.; FORTIN, J.A. Root colonization and intraspecific mycobiont variation in ectomycorrhiza. Symbiosis, v.8, p.197-231, 1990. 